\title{
ANTIOXIDANT ROLE OF PROPOLIS ON SODIUM FLUORIDE HEPATO-RENAL TOXICITY IN ALBINO RABBITS: PATHOLOGICAL STUDY
}

\author{
HANAA A. EL-HALLAWANY ${ }^{1}$ and ABEER, E. EL-METWALLY ${ }^{2}$ \\ ${ }^{1,2}$ Pathology Dept., Animal Reproduction Research Institute (A.R.R.I.)
}

Received: 17 May 2017; $\quad$ Accepted: 12 July 2017

\begin{abstract}
ABESTRACT
Fluoride anion is an agent which contributes to the dental protection and prevents osteoporosis in small doses, but in case of excessive exposure, it can interfere with metabolic pathways involving lipids, carbohydrates and proteins. Propolis is a compound formed by honeybees and considered as a common antioxidant. This study was designed to investigate the beneficial role of propolis as natural antioxidant against chronic sodium fluoride hepato-renal toxicity in albino rabbits. Four experimental groups receiving a combination of sodium fluoride (10 $\mathrm{mg} / \mathrm{kg}$ body weight/day) and/or propolis $(25 \mathrm{mg} / \mathrm{kg}$ body weight/day) for 60 -day was divided as follows: no treatment (control), sodium fluoride alone, propolis alone and sod fluoride + propolis. Histopathological and histochemical results revealed that tissue alterations in both liver and kidney were present only in fluoride treated group. There was hepatocellular necrosis, extensive vacuolization and inflammatory cell infiltrations in the liver. However, the kidneys exhibited increasing amounts of cloudy swellings, degeneration of tubular epithelia, tissue necrosis, and extensive vacuolization in renal tubules as well as atrophy of glomeruli, interstitial oedema and interstitial nephritis. These hepato-renal toxic disturbances induced by fluoride reflect functional and structural alterations in the tissues. On the other hand, administration of propolis either alone or combined with sod fluoride pronounced or even complete recovery this hepato-renal toxicity. In addition to, the morphological analysis of apoptosis of liver and kidney tissues showed massive necrosis and increased rate of apoptosis in sodium fluoride only treated group. While in Propolis only and /or fluoride treated groups, there was low level in apoptosis. The conclusion of the present study suggests that the propolis is strong antioxidants and free radical scavengers that ameliorated the chronic hepato-renal toxicity induced by sodium fluoride in the albino rabbits.
\end{abstract}

Key words: Sodium Fluoride, Propolis, Hepato- renal toxicity, Apoptosis, Histopathology, Histochemical, Rabbit.

\section{INTRODUCTION}

Although fluoride intake is necessary for the development of teeth and body skeleton but its requirements are in traces. It can occur naturally in surface water as a result of atmospheric deposition of fluoride particles as well as fluoride-containing rocks as leaching from rocks and soils. Ground water and chemical manufacturing waste products can pollute water sources with excess fluoride. (ATSDR, 2003 and Bhatnagar et al., 2011). High levels of fluoride in drinking water have been a potential hazard all over the world as a result of increased in dustriazation and environmental pollution (Susheela et al., 2013). Egypt is one of about 21 developing nations that have problems with endemic fluorosis, where the main pathway of fluorosis, is the ingestion of tap water from contaminated ground water sources.

Corresponding author: Dr. HANAA A. EL-HALLAWANY E-mail address: hanaeg2002@yahoo.com

Present address: Pathology Dept., Animal Reproduction Research Institute (A.R.R.I.)
The fluoride concentration in industrial waste water samples collected from Abu Zabaal and Ahlia areas around Cairo vary from 1.13 to $7.10 \mathrm{mg} / \mathrm{L}$, significantly exceeding the World Health Organization recommended maximum $1 \mathrm{mg} \mathrm{F} / \mathrm{L}$ (Helaland El Dakdoky, 2006). The source of drinking water in Marsa Matrouh and Arish governorates, Egypt is groundwater that coming from artesian wells and contained higher levels of fluoride with an average of 0.761 and $0.926 \mathrm{mg} / \mathrm{L}$, respectively (Ibrahim et al., 2013).

However, fluoride toxicity pathogenesis resulting by crosses the cell membrane very rapidly and distributed from the plasma to all tissue and organs which exerts an oxidative stress leading to generation of frees radicals of reactive oxygen species (ROS) and alterations in antioxidants or scavenging enzymes and finally resulting in histopathological alterations and apoptosis indifferent tissues (Bouaziz et al., 2006; Khandare et al., 2011 and Agha et al., 2012). Apoptosis is the maintenance of tissue homeostasis involves in the removal of superfluous and damaged 
cells. Apoptic cells eventually were swollen due to degeneration then nucleus fragmentation with condensation of the cytoplasm to produce membranebound apoptotic bodies that are phagocytosed by macrophages (Reed, 2001).

Propolisis natural sticky substances produced by honey bees by mixing their waxes with resinous sapand also known as bee glue (Yoshimi et al., 2009 and Alqayim, 2015). Nowadays propolis is reported to inhibit the generation of superoxide anion. Furthermore, propolis has been determined to reverse the consumption of glutathione, which is synthesized in the liver and has radical scavenging activity (Survswaron et al., 2007and Khalil and El-Sheikh, 2010). As well as propolis has an anabolic effect as it is rich in essential amino acids, protein, unsaturated fatty acids and also improves the digestive utilization of calcium, phosphorus and magnesium which contribute to the health effects (Campos et al., 2003). In modern times, it has been found to have a wide range of biological activities, such as being antibacterial (Oris et al., 2005), anti-inflammatory (Yoshizumi et al., 2005), anticarcinogenic (Aliyazicioglu et al., 2005), antioxidative (Kanbur et al., 2009) and immunomodulatory effects (Sforcin, 2007).

This study was designed to investigate the beneficial role of propolis as natural strong antioxidant against chronic sodium fluoride hepato-renal toxicity in albino rabbits.

\section{MATERIALS AND METHODS}

\section{I - Animals:}

Twenty healthy adult New Zealand white male rabbits of the same age, with a weight range of 2-2.5 $\mathrm{kg}$ was used for this study. They were housed in a well-ventilated animal house and each group caged separately, at a temperature of $29-32^{\circ} \mathrm{C}$. The animals exposed to $10-12 \mathrm{~h}$ of daylight under proper hygienic conditions and received food and water ad libitum. All animals were acclimatized for one week before being dosed. The present study was carried out in Animal Reproduction Research Institute (A.R.R.I.).

\section{II - Chemicals:}

1- Sodium Fluoride (NaF): Crystalline powder natriumfluoride (Sigma, Germany) was dissolved in tap water from El Gomhoria Company for Chemical and Medical Trading, Egypt.

2- Propolis preparation: Egyptian propolis was commercial purchased beeswax honeycomb processing. The propolis adjuvant was prepared as previously described (Shaapan et al., 2014). The dose of the drug was determined by LD50 test according to Purohit et al. (2013).

\section{III - Animal groups and dose administration:}

It was applied according to Khandare et al. (2011). The rabbits were divided into four equal groups of five each.

1 - Control group (GP I): Animals were given water without any treatment.

2 - NaF group (GP II): Animals were provided $10 \mathrm{mg}$ $\mathrm{NaF} / \mathrm{kg}$ b.w.

3 - Propolis group (GP III): Animals were given $25 \mathrm{mg}$ propolis $/ \mathrm{kg}$ b.w.

4 - NaF+ propolis group (GP IV): Animals were given $10 \mathrm{mg} \mathrm{NaF} / \mathrm{kg}$ b.w.+ $25 \mathrm{mg}$ propolis $/ \mathrm{kg}$ b.w.

All experimental animals were given different treatment daily in drinking water for 60-day. At the end of experiment, animals were sacrificed and liver and kidneys were taken for histopathological and histochemical studies as well as morphological assessment of apoptosis.

\section{IV - Pathological studies:}

1- Histopathological examination: liver and kidneys were taken and preserved in a $10 \%$ neutral formalin solution for fixation, then dehydrated through ascending grades of alcohol, cleared in xylene and embedded and blocked in paraffin. Sections of 3-5$\mu \mathrm{m}$ thickness were taken and stained with hematoxylin and eosin then examined under the microscope. All these procedures were applied as previously described by Suvarna et al. (2013).

2- Histochemical examination: Periodic acid schiff (PAS) reaction was applied to demonstrate carbohydrates and Masson's Trichrome stain was used for connective tissue proliferation demonestration. All these procedures were applied as previously described by Suvarna et al. (2013). As well as Bromophenol, blue stains were performed according to Mazia et al. (1953)

3- Morphological assessment of apoptosis: Paraffin tissue sections were fixed on positive charged microscope slides, stained with an Acridine orange (A.O) / Ethidium bromide (E.B) mixture and viewed under a UV microscope as described by Dhama et al. (2002), the viable cells and early apoptotic cells appeared fluoresce green, while the nuclei in necrotic cells appeared fluoresce orange red.

\section{RESULTS}

\section{I - Clinical signs:}

Chronic exposure to fluoride for a period of 60 days induced deleterious impacts in animals under experiment. First symptoms of chronic fluoride toxicity are reduced feed intake as a result of loss of appetite that leading to emaciation. Also, transient diarrhea and/or constipation were seen. In addition to, nervous manifestation included muscle tremor, weakness, pupilary dilatation and hyperesthesia as 
well as lethargy. While groups treated with propolis with fluoride and propolis only didn't show any of these symptoms.

\section{II - Histopathological Examination:}

\section{1- Liver:}

In the present study, the gross examination of the rabbit's liver of GP II(10mg NaF group) treated groups was pale enlarged with pen headed white foci on them comparing with the normal appearance of normal group. Microscopically, liver of control group (GP I) revealed that normal lobular pattern of hepatic cords. Comparing to the control group, hepatocytes ballooning degeneration with numerous centrilobular necrotic foci in addition to, moderate leukocytic cell infiltration was also observed in certain areas (Fig. 1).The central vein and hepatic sinusoids appeared dilated as well as bile duct proliferation and periportal fibrosis was also observed (Fig. 2). Periportal fibrosis were detected with Massontrichromestain (Fig. 3).

On the other side, nomacroscopical or microscopical histopathological changes were noticed in the examined livers of GPIII (Propolisonly treated) rabbits comparable to the control group except a very slight dilatation of blood sinusoids that denotes increased blood flow in these vessels. On the other hand, the macroscopic examination of liver of GP IV (Propolis with sod fluoride group) showed nearly normal size and color without any foci on their surfaces. Microscopically, animals showed no evidence of ballooning or degeneration but Kupffer cell proliferation was observed around the dilated sinusoidal vessels. Moreover, hepatic focal cell necrosis, and periportal mononuclear cell infiltration or fibrosis was absent compared to GP II (NaF treated group) (Fig. 4).

\section{2- Kidney:}

In this work, the gross examination of the kidneys in the fluoridated rabbits (Gp II) appeared congested and moderately enlargement comparing to control group kidneys. Histopathologically, a pronounced cellular degeneration with vacuolated cytoplasm and necrosis in the epithelial lining of convoluted tubules were seen (Fig.5). The glomeruli and their capsules appeared atrophied with interstitial nephritis and associated with perivascular oedema (Fig.6).

Concerning with the effect of propolis supplementation, it was cleared that, propolisdoes not have a protective effect against sod fluoride induced nephrotoxicity, gross nor microscopic lesions were detected in the examined rabbit kidneys of both GPIII and GP IV except mildcongestion with focal vacuolar tubular degeneration were seen in Gp IV (Fig.7).

\section{III - Histochemical Examination:}

1- Liver: Histochemically, we detected PAS-positive material was diffusely distributed in the form of purple granules of glycogen in the hepatic cells in control Gp I. Comparing to GP I, hepatocytes appeared markedly with less PAS-positive matter of glycogen particles in GPII (Fig. 8). On the other hand, in GP III and GP IV the polysaccharides appeared more or less like control (Fig. 9).Moreover, bromophenol blue stain in GPII revealed that fluoride caused a noticed decrease in the protein content in cytoplasm of hepatocytes (Fig. 10) while in GP III and GP IV, propilais showed a marked a preservative effect on protein content of hepatocytes (Fig. 11).

2- Kidney: The histochemical examination of the kidney of Gp I, III and IV rabbits in this work showed the presence of polysaccharides in the form of PAS positive materials in capillaries of the glomeruli, the basement membrane of the proximal and distal convoluted tubules which indicated that the polysaccharides of kidneys appeared more or less as control (Fig. 12). While fluoridated rabbits (Gp II) showed an decrease in the PAS +ve material as well as the basement membranes of the proximal and distal convoluted tubules appear thicker as compared with the control one (Fig. 13). In addition to, bromophenol blue stain in GPII showed a noticed decrease in the protein content in cytoplasm of tubular cells (Fig. 14) comparing to GP III and GP IV, which revealing that propilais have a preservative effect on protein content of renal tubular cells (Fig. $15)$.

\section{IV - Morphological analysis of apoptosis:}

The treatment by A.O. and E.B. described here, by which necrosis and apoptosis can be recognized. Early apoptotic cells excluded the ethidium bromide, but were permeable to acridine orange, that gave DNA green fluorescent. Early apoptotic cells contain bright dots of characteristic condensed chromatin in their nuclei. While in late apoptosis with loss of membrane integrity, both dyes enter the cell and the nucleus is stained orange-red. Necrotic cells also stain in orange, but nuclear morphology resembling that of viable cells.

Tissue examination in GpII showed marked increased levels of apoptosis associated with severe necrosis among the hepatic tissue with increased numbers of apoptotic hepatocytes in the periportal regions, the nuclei of these cells were enlarged, hyperchromatic and pleomorphic with a coarse chromatin pattern (Fig.16). Moreover, there was obvious apoptosis of renal tissues as represented by marked apoptosis of epithelial cells lining tubules and glomeruli (Fig: 17). On the other hand, both GpIII (Fig. 18) and GpIV showed hepatic and renal protection approaching to the control group which was reflected as green florescence color of tissues (Fig: 19\&20). 


\section{FIGURES}

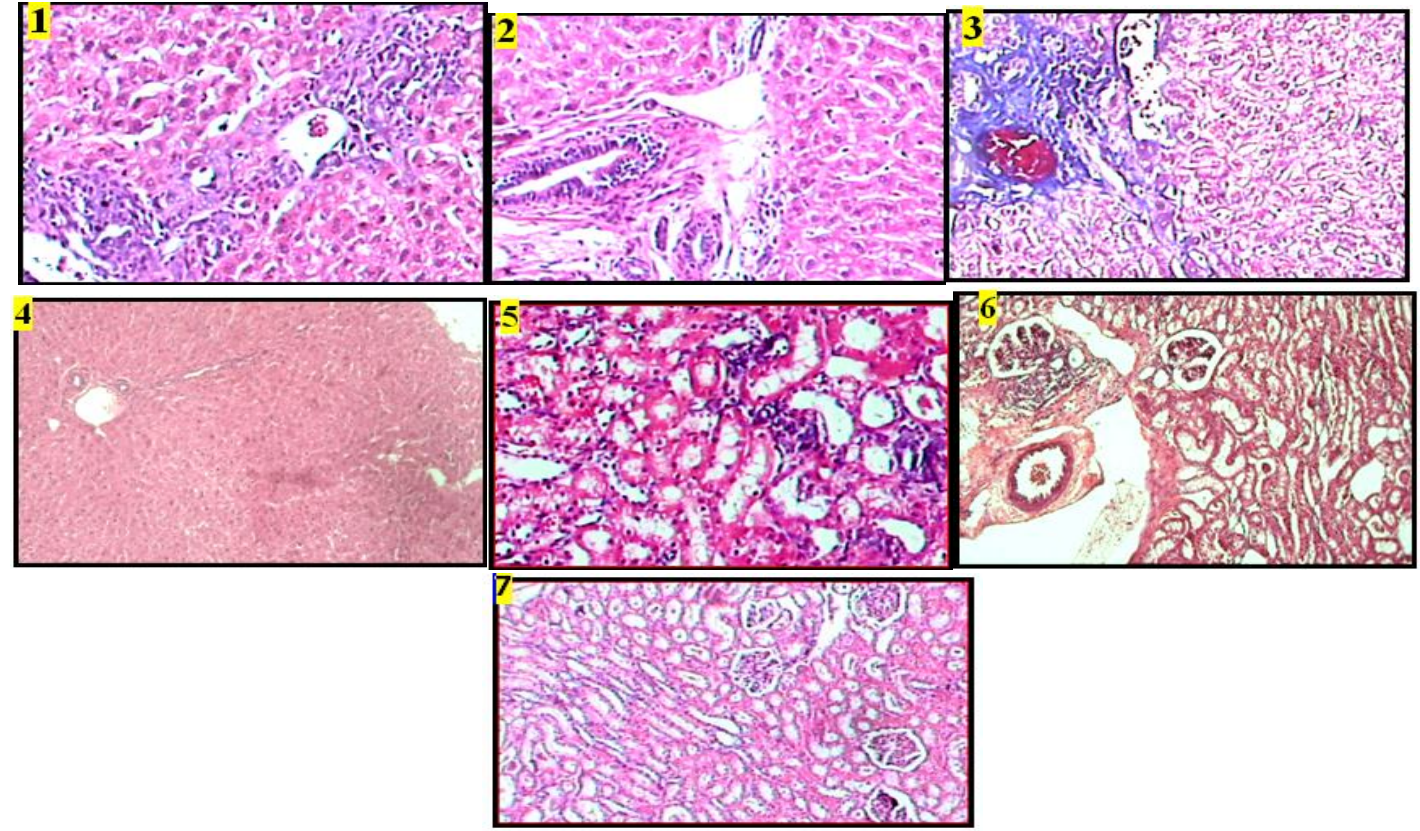

Fig. 1: Rabbit liver (GII) showing, Focal lymphocytic infiltration replaces the hepatic parenchyma (H\&E X10).

Fig.2: Rabbit liver (GII) showing peri portal fibroblastic proliferation with bile duct epithelial lining hyperplastic changes associated with lymphocytic exocytosis (H\&E X10).

Fig. 3: Rabbit liver (GII) showing perivascular and periportal blue band of Collagen fiber (Masson-trichrome stain X10)

Fig. 4: Rabbit liver (G IV) showing showed prominent hepatic tissue restoration except mild hepatic cords distortion without congestion as well as few limited hepatocyticvacculation (H\&E X4).

Fig.5: Rabbit kidney (GpII) showing glomerular and tubular degeneration with mononuclear cell infiltrations (H\&E, X10).

Fig. 6: Rabbit kidney (Gp II) showing vascular congestion with glomerular shrinkage and perivascular edema (H\&E, X10).

Fig. 7: Rabbit kidney (G IV) showing mild congestion with focal vacuolar tubular degeneration (H\&E, X10).
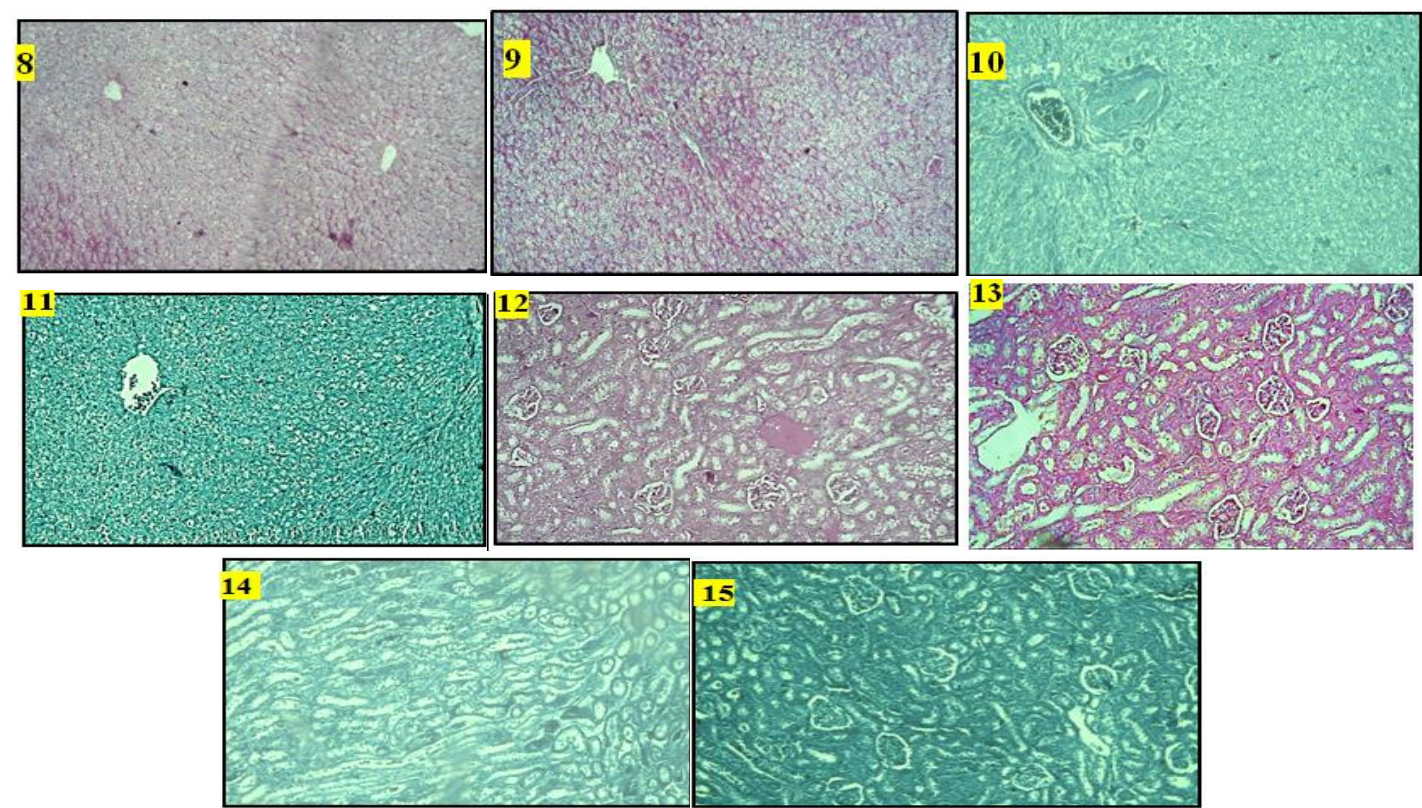

Fig. 8: Rabbit liver (GII) hepatocytes appeared markedly with less PAS-positive matter of glycogen particles showing (PAS, X10).

Fig. 9: Rabbit liver (GIV) PAS-positive material of glycogen particles distributed diffusely in the form of purple granules of glycogen in the hepatic cells (PAS, X10)

Fig. 10: Rabbit liver (GpII) showing a noticed decrease in the protein content in cytoplasm of hepatocytes (Bromophenol blue stain X10).

Fig. 11: Rabbit liver (GpIV) showing showed the marked preservative effect of propilais on protein content of hepatocytes (Bromophenol blue stain X10).

Fig. 12: Rabbit kidney (GpIV) showed the presence of polysaccharides in the form of PAS positive materials in capillaries of the glomeruli, the basement membrane of the proximal and distal convoluted tubules (PAS, X10).

Fig. 13: Rabbit kidney (GpII) showed decrease in the PAS +ve material as well as the basement membranes of the proximal and distal convoluted tubules (PAS, X10).

Fig.14: Rabbit kidney (GpII) showed the decrease in the protein content in cytoplasm of tubular cells (Bromophenol blue stain X10).

Fig. 15: Rabbit kidney (Gp IV) showing that propilais have a preservative effect on protein content of renal tubular cells (Bromophenol blue stain X10) 

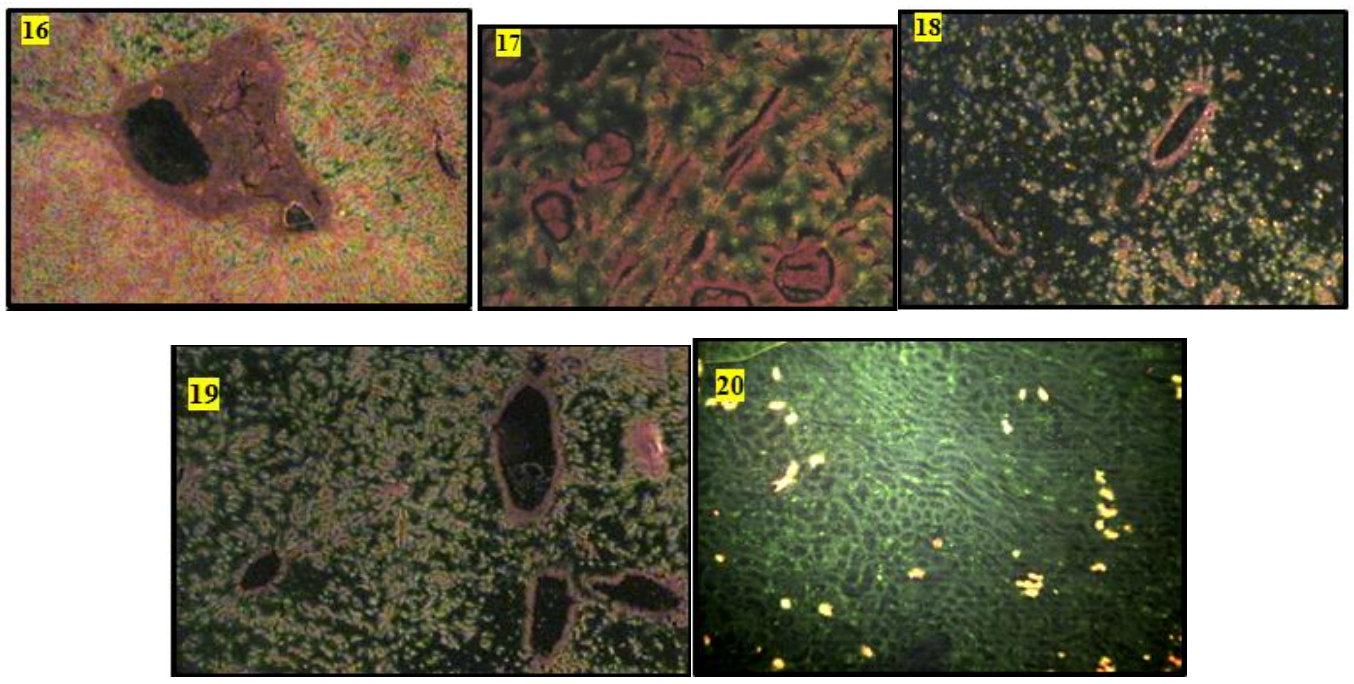

Fig.16: Rabbit liver (Gp II) showing obvious apoptosis in hepatic cells (strong orange fluorescent color) accompanied with necrotic and early apoptotic hepatocytes (green fluorescent for viable cells) (A. O and E. B., X 4).

Fig.17: Rabbit kidney (Gp II) showing prominent apoptosis of in most tubules of renal tissues and glomeruli as well as necrotic cells (A. O and E. B., X 10).

Fig.18: Rabbit liver (Gp III) showing less apoptosis level and necrotic hepatocytes (A. O and E. B., X 4).

Fig.19: Rabbit liver (Gp IV) showing less apoptosis level and necrotic hepatocytes (A. O and E. B., X 4).

Fig.20: Rabbit kidney (Gp IV) showing less apoptosis of in some tubules renal tissues (A. O and E. B., X 4).

\section{DISCUSSION}

Fluoride intake (fluorosis) usually occurs in two forms; endemic fluorosis, related to intake of drinking water with high fluoride contents and industrial fluorosis, which has been found to cause severe side effects, to the soft tissues like liver and, kidney (Wang and Li, 2002). Various studies demonstrated that elevated levels of serum hepatic and renal enzymes have been found following fluoride intoxication that indicating degenerative and inflammatory damages to the liver and kidney (Wang et al., 2004 and Anjum et al., 2014).

Numerous reports indicated that excessive fluoride and chronic fluorosis can enhance lipid peroxidation and inhibits the oxidative enzymes in the body organs that resulting in metabolic, functional and structural damages and apoptosis as a result of massive cellular damage in many tissues, including liver (GruckaMamczar et al., 2009) and kidney (Shashi et al., 2001 and Nabavi et al., 2013), Also, this toxicity is accompanied by a decline in activities of antioxidant enzymes, as well as reducing substances like glutathione and ascorbic acid (Helal and El Dakdoky, 2006). It is evidently indicated that fluoride can disturb the metabolism of proteins and impair the activities of a series of enzymes (Agha et al., 2012 and Khudiar and Aldabaj, 2015). Mentioned signs in this work were agreed with the finding of Bataineh and Nusier (2006); Lohakare et al. (2010) and Bharti et al. (2017).
In this study, the noticed body weight reduction might be attributed to the decrease in feed consumption and transient diarrhea occurred which considered as a first symptoms of chronic F toxicity. Moreover, Ulemale et al. (2010) returned the decrease in feed consumption to gastroenteritis as a formation of hydrofluoric acid.

Liver is a critical organ of vital importance and very active site of metabolism, in which most of accumulated metals and toxins harmful effects can be detoxicated, especially fluoride toxicity (Chinoy et al., 2004). Earlier studies showed that fluoride can produce abnormalities in the liver including degenerative and inflammatory changes (Shashi and Thapur, 2001). Fluoride consumption for a long period of time has many pathological effects as a result of increased oxidative stress on soft tissues like liver and endocrine organs by simple diffusion (Sahu et al., 2015).

Noticed histopathological changes in fluoride-treated rabbits GP II Liver in the present study nearly similar to those previously reported by Shashi and Thapur (2001) and Ersan et al. (2010) in the liver of mice exposed to $10 \mathrm{ppm} \mathrm{NaF}$ and Podder et al. (2011) who used $15 \mathrm{mg} \mathrm{NaF} / \mathrm{L}$ for 30 days in mice. Whilethe noticed histopathological changes in both GP III and GP IV correlated to those observed by Mathivanan et al. (2013) and Barakat et al. (2015) who administrated propolis as a hepato-protective against hepatoxic effects of alcohol and boldenoneundecylenate in mice and rats, respectively. 
Moreover, Abdel-Wahab (2013) used thymoquinone against hepatotoxicity and oxidative stress of sodium fluoride in rats.

Kidneys are the primary organs concerned with excretion and for retention of fluoride so they are the target organs for chronic fluoride toxicity. They are the most sensitive body organs in their histopathological and functional responses to excessive amounts of fluoride (Shashi et al., 2001 and Inkielewicz and Krechniaka, 2008). Their toxicity appeared as tubular degeneration, inflammation, fibrosis, parenchymatous nephritis, and dilatation of convoluted tubules in rats ingested high fluoride water (Ersan et al., 2010).

The gross and microscopic changes were noticed in kidneys of ( $\mathrm{Gp} \mathrm{II)} \mathrm{in} \mathrm{this} \mathrm{work} \mathrm{were} \mathrm{similar} \mathrm{to} \mathrm{those}$ previously observed by Shashi et al. (2002) in rabbits and Zhan et al. (2006) in pig and Podder et al. (2011) who used $15 \mathrm{mg} \mathrm{NaF/L}$ for 30 days in mice Similar results obtained by Barakat et al. (2015) and Osman and Tantaway (2013) who used propolis to improving the renal damage induced by boldenoneundecylenate and gentamicin in rats, respectively. In addition to, flouride nephrotoxicity explained by $\mathrm{Kim}$ et al. (2008) and El-Masry et al. (2011) as propolis increases the levels of both vitamin $\mathrm{E}$ and vitamin $\mathrm{C}$ which are increasing the antioxidant capacity of the cells and inhibiting the ROS generation, resulting in a decrease in both lipid peroxidation and protein oxidation. Our findings parallel with Kołodziejczyk et al. (2004) who used flavonoid Chrysin for amelioration of structural changes in the liver and kidneys of rats subchronically exposed to sodium fluoride. Błaszczyk et al. (2008) mentioned methionine and vitamin $\mathrm{E}$ were used as antioxidant against fluoride renal toxicity in rat kidney. Similar, Khudiar and Aldabaj (2015) used grape seed extract as anti-oxidant to rabbit treated with $100 \mathrm{ppm} \mathrm{NaF}$ for 60 days. Approaching of our results, Tavakkoli et al. (2017) used black seed as a protective agent against sodium fluoride.

In the present study, the histochemicalexamination of both livers and kidneys were correlated with Abou El-Soud and Khalil (2010) and El-Khayat et al. (2010) results who were administrated onion oil and garlic oil as heap to renal protective in diabetic rats. Which explained as cytotoxic agents as fluoride may lead to severe oxidative damage of the liver cells cellular components like cell membrane, lipids, proteins and DNA (Wang et al., 2005).

Different studies confirmed the mechanisms of antioxidant action may include suppression of ROS formation, scavenging of reactive oxygen species and protection of antioxidant defenses, so they have a preventive action which could reduce cell death and blocking apoptosis in different cellular structures caused by oxidants and free radicals that induced by sodium fluoride as recorded by Montoro et al. (2005) and Agha et al. (2012). So, propolis showed noticeable alleviation in liver and kidneys histopathological and histochemical changes which caused by sodium fluoride. As fluoride interacts and alters the metabolism of calcium and magnesium, the decrease in serum calcium related to decrease of intestinal absorption of calcium by fluoride (Xin et al., 2006). The antioxidant and ROS scavenging properties of propolis referred to its contents of considerable amounts of flavonoids, phenolic acids and polyphenol substances as caffeic acid phenyl ester (CAPE) which act as potent antioxidant that plays a role in scavenging of ROS, metal ion chelation and synergistic action with other antioxidant compounds (Wagh, 2013 and KurekGórecka et al., 2014). So, propilis have renal and hepatic protective role as well as some regenerative properties as recorded previously by Sales et al. (2006) and Chandna et al. (2014).

\section{CONCLUSION}

The conclusion of the present study suggests that the propolisas strong antioxidants and free radical scavengers, ameliorate the toxic effect of sodium fluoride that induce histopathological changes in both liver and kidneys of albino rabbits.

\section{REFRENCES}

Abdel-Wahab, W.M. (2013): Protective effect of thymoquinone on sodium fluoride-induced hepatotoxicity and oxidative stress in rats. J. Basic Appl. Zool. 66: 263-70.

Agha, FE.; El-Badry, MO.; Hassan, D.A. and AbdElraouf, A. (2012): Role of Vitamin E in Combination with Methionine and Lcarnosine Against Sodium Fluoride-Induced Hematological, Biochemical, DNA Damage, Histological and Immunohistochemical Changes in Pancreas of Albino Rats. Life sci J; 9(2):1260-1275.

Aliyazicioglu, Y.; Deger, O.; Ovali, E.; Barlak, Y.; Hosver, I.; Tekelioglu, Y. and Karahan, S.C. (2005): Effects of Turkish pollen and propolis extracts on respiratory burst for K-562 cell lines. Int. Immunopharmacol. 5(11):1652-7.

Anjum, K.M.; Mughal, M.S.; Sayyed, U.; Yaqub, A.; Khalique; A.; Rashid, M.A.; Yousaf, M.Z.; and Mumtaz, N. (2014): Influence of increasing fluoride dose rates on selected liver and kidney enzymes profile in domestic chicken (Gallus domesticus) The Journal of Animal \& Plant Sciences, 24(1): 77-80.

Atsdr (Agency for Toxic Substances and Disease Registry) (2003): Toxicological profile for fluorides, hydrogen fluoride, and fluorine. Division of Toxicology /Toxicology Information Branch.: 1-351. 
Alqayim, MA.J. (2015): Propolis cardio protective role from the impact of Aluminum chloride in female rabbits. Bas.J.Vet.Res. 14 (2):136- 149.

Barakat, LA.; Tousson, A E.; Ibrahim, W. and Abd El-Hakeem, A. (2015): Role of propolis in improving hepatic and renal damage in boldenoneundecylenate in male rats. American Journal of Biological Chemistry; 3(1): 8-15.

Bataineh, H.N. and Nusier, M.K. (2006): Impact of 12- week ingestion of sodium fluoride on aggression, sexual behviour and fertility in adult male rats. Fluoride; 39(4):293-301.

Bharti, V.K.; Giri, A. and Kumar, K. (2017): Fluoride Sources, Toxicity and Its Amelioration: A Review. Peertechz J Environ Sci Toxicol 2(1): 021-032.

Bhatnagar, A.; Kumar, E. and Sillanpää, M. (2011): Fluoride removal from water by adsorptionareview. Chem. Eng. J. 171(3):811-840.

Błaszczyk, I.; Grucka-Mam, czar, E.; Kasperczyk, S. and Birkner, E. (2008): Influence of Fluoride on Rat Kidney Antioxidant System: Effects of Methionine and Vitamin E. Biol Trace Elem Res; 121:51-59.

Bouaziz, H.; Ketata, S.; Jammoussi, K.; Boudawara, T.; Ayedi, F.; Ellouze, F. and Zeghal, N. (2006): Effects of sodium fluoride on hepatic toxicity in adult mice and their suckling pups. Pestic. Biochem. Physiol. 86: 124-130.

Campos, M.G.; Webby, R.F. and Markhan, K.R. (2003): Age-induced diminution of free radical scavenging capacity in bee pollens and the contribution of constituent flavonoids. J. Agric. Food Chem., 51(3): 742-745.

Chandna, P.; Vivek, K.A.; Das, S. and Singh, S. (2014): Complementary and Alternative Medicine (CAM): A Review of Propolis in Dentistry American Journal of Phytomedicine and Clinical Therapeutics AJPCT; 2(6): 670685.

Chinoy, N.J.; Sharma, A.K.; Patel, T.N.; Memon, R. and Jhala, D.D. (2004): Recovery from fluoride and aluminium induced free radical liver toxicity in mice fluoride 37(4): 257-263.

Dhama, K.; Kataria, J.M.; Dash, B.B.; Natesan S. and Tomar, S. (2002): Chicken infectious anaemia (CIA): a review. Ind. J. Comp. Microbiol. Immunol. Infect Dis., 23: 1-15.

El-Khayat, Z.; WafaaRasheed; Tahany Ramzy; Jihan Hussein; Mervat Agaiby; Safaa Morsy; Fatma Morsy and Nermeen Shaffie (2010): Protective effect of garlic oil against liver injury in experimental animals 2Journal of Medicinal Plants Research Vol. 4(22), pp. 2359-2369, 18 November,

El-Masry, TA.; Ashraf, ME. and El-Shitany, NA. (2011): Possible protective effect of propolis against lead-induced neurotoxicity in animal model. J. Evol. Biol. Res. 3:4-11.

Ersan, Y.; Koc, E. and AriI, Karademir, B. (2010): Histopathological effects of chronic fluorosis on the liver of mice (Swiss albino). Turk $\mathbf{J}$ Med. Sci.; 40 (4): 619-622.

Grucka-Mamczar, E.; Zalejska-Fiolka, J.; Chlubek, D.; Kasperczyk, S.; Błaszczyk, U.; Kasperczyk, A.; Swietochowska, E. and Birkner, E. (2009): The influence of sodium fluoride and caffeine on the activity of antioxidative enzymes and the concentration of malondialdehyde in rat liver. Fluoride. 42: 105-109.

Helal, M. and El Dakdoky, M. (2006): Fetotoxicity of fluoride in rats and the protective action of some antioxidants. Fluoride; 39(3): 202-210.

Ibrahim, AA.; Raafat, N. and Ibrahim, NA. (2013): Protective effect of curcumin against toxic effects of sodium fluoride on lungs of adult male albino rats. British Journal of Science; 29, 9(1): 2047-3745.

Inkielewicz, I. and Czarnowski, W. (2008): Oxidative stress parameters in rats exposed to fluoride and aspirin. Fluoride. 41: 76-82.

Kanbur, M.; Eraslan, G.; Silici, S. and Karabacak, M. (2009): Effects of sodium fluoride exposure on some biochemical parameters in mice: Evaluation of the ameliorative effect of royal jelly applications on these parameters. Food and Chemical Toxicology; 47: 1184-1189.

Khalil, FA. and El-Sheikh, NM. (2010): The effects of dietary Egyptian Propolis and Bee pollen supplementation against toxicity if sodium fluoride in rats. Journal of American Science; 6, (11): 310-316.

Khandare, A.; Kumar, U. and Rao, S. (2011): Magnesium hydroxide for protection against fluoride toxicity in rabbits. Fluoride; 44(1):2126.

Khudiar, K.K. and Aldabaj, A.M.A. (2015): Effect of grape seed oil on hepatic function in adult male rabbits treated with sodium fluoride (Part-II). Adv. Anim. Vet. Sci. 3(10): 550-558.

Kim, J.E.; Jin, D.H.; Lee, S.D.; Hong, S.W.; Shin, J.S.; Lee, S.K.; Jung, D.J.; Kang, J.S. and Lee, W.J. (2008): Vitamin C inhibits p53-induced replicative senescence through suppression of ROS production and p38 MAPK activity. Int $\mathbf{J}$ Mol Med 22:651-655.

Kurek-Górecka, A.; Rzepecka-Stojko, A.; Górecki, M.; Stojko, J.; Sosada, M. and SwierczekZieba, G. (2014): Structure and Antioxidant Activity of Polyphenols Derived from Propolis. Molecules; 19(1): 78-101.

Kołodziejczyk, L.; Grygiel, WK. and Myśliwiec, Z. (2004): Protective effect of chrysin in rats subchronically exposed to sodium fluoride Fluoride; 37(3): 209-20.

Lohakare, J.; Pattanaik, A. and Khan, S.A. (2010): Effect of long-term fluoride exposure on growth, nutrient utilization and fluoride kinetics of calves fed graded levels of dietary protein. Biol Trace Elem Res 138: 148-162. 
Mathivanan, V.; Gh, N.S.; Manzoor, M.; Mir and Selvisab, G.M. (2013): A Review on Propolis As a Novel Folk Medicine A Indian Journal of Science, Volume 2, Number 3, January

Mazia, D.; Drewer, PA. and Alfert, M. (1953): The cytochemical staining and measurement of protein with mercaricbromophenol blue. Biol. Bull., 104: 57-67.

Montoro, P.; Braca, A.; Pizz, C. and De Tomasi, N. (2005): $\quad$ Structure-antioxidant acivity relationships of flaconoids isolated from different plant species. Food Chem. 92: 349355.

Nabavi, S.M.; Habtemariam, S.; Nabavi, S.F.; Suredo, A.; Daglia, M.; Moghaddam, A.H. and Amari, M.A. (2013): Protective effect of gallic acid isolated from Peltiphyllumpeltatum against sodium fluoride -induced oxidative stress in rat kidney. Mol. Cell. Biochem. 372(1-2): 233-239.

Oris, R.O.; Sforcin, J.M.; Funri, S.R. and Bankova, V. (2005): Effects of Brazilian and Bulgarian propolis on bactericidal activity of macrophages against salmonella Typhimurium. Int. Immunolpharmacol.; 5(2): 359-68.

Osman, I.H. and Tantaway, A. (2013): Antioxidant activity and propolis on gentamicin induced nephrotoxicity in rabbits in protective effects of commercial vitro study Türk Biyokimya Dergisi [Turkish Journal of BiochemistryTurk J. Biochem]; 38 (4): 409-415.

Podder, S.; Agarwal, S. and Bhattacharya, S. (2011): Fluoride-induced histopathology and synthesis of stress protein in liver and kidney of mice. Ansuman Chattopadhyay; 85(4): 327-335.

Purohit, A.; Joshi, K.; Kotru, B. and Kotru, S. (2013): Effect of Indian propolis on haematological parameters in experimentally induced hyperlipidemic male albino rabbits. Asian Journal of Pharmaceutical and Clinical Research; 6 (1): 17-19.

Reed, J.C. (2001): Apoptosis-regulating proteins as targets for drug discovery. Trends in Molecular Medicine, 7: 314-319.

Sahu, S.K.; Mishra, D.N.; Pradhan, S.; Prusti, J.S.; Panda, S.K.; Agrawal, D.; Sahu, M.C. and Arora, G. (2015): Fluoride induced histopathological changes in liver of albino rabbit - an experimental study. Int. J. Pharm. Sci. Rev. Res., 30(2): 184-188.

Sales, A.; Alvarez, A.; Areal, M.R.; Maldonado, L.; Marchisio, P.; Rodríguez, $\quad M$. and Bedascarrasbure, E. (2006): The effect of different propolis harvest methods on its lead contents determined by ET AAS and UV-visS. J Hazard Mater; 137(3):1352-6.

Sforcin, J.M. (2007): Propolis and the immune system: a review, J. Ethnopharmacol. 1131 14
Shaapan, R.M. and Zeedan, G.S.G. (2014): Immunostimulant Effect of Egyptian Propolis Extract against Parapox virus in experimental Rats. Nature and Science; 12(2): 20- 25.

Shashi, A. and Thapur, S.P. (2001): Histopathology of fluoride-induced hepatotoxicity in rabbits. Fluoride 2001; 34(1): 34-42.

Shashi, A.; Singh, J.P. and Thapar, S.P. (2002): Toxic effects of fluoride on rabbit kidney38 Fluoride; 35 (1): 38-50.

Shashi, A.; Singh, J.P. and Thapur, S.P. (2001): Toxic effects of fluoride on rabbit kidney. Fluoride; 35 (1): 38-50.

Surveswaron, S.; Cai, Y.Z.; Carke, H. and Sun, M. (2007): Systematic evaluation of natural phenolic antioxidants from 133 Indian medicinal plant. Food Chem. 102: 938-953.

Susheela, AK.; Mondal, NK. and Singh, A. (2013): Exposure to fluoridein smelter workers in a primary aluminum industry in India. Int. J. Occupat. Environ. Med. 4(2): 61-71.

Suvarna, K.S.; Layton, C. and Bancroft, J.D. (2013): Bancroft's Theory and Practice of Histological Techniques, by Suvarna, 7th Edition Churchill Livingstone.

Tavakkoli, A.; Ahmadi, A.; Razavi, M.B. and Hosseinzadeh, H. (2017): Black seed (Nigella Sativa) and its constituent Thymoquinone as an antidote or a protective agent against natural or chemical toxicities. Iranian Journal of Pharmaceutical Research; 15: 2-23.

Ulemale, A.H.; Kulkarni, M.D.; Yadav, G.B.; Samant, S.R.; Komatwar S.J. and Khanvilkar, A.V. (2010): Fluorosis in Cattle Veterinary World; 3 (11): 526-527.

Wagh, VD. (2013): Propolis: A Wonder Bees Product and Its Pharmacological Potentials. Adv Pharmacol Sci. 308249.

Wang, H.; Wei, W.; Zhang, SY.; Shen, YX.; Yue, L. and Wang, LP. (2005): Melatonin-selenium nanoparticles inhibit oxidative stress and protect against hepatic injury induced by Bacillus Calmette- Guerin/lipopolysaccharide in mice. J. Pineal. Res., 39(2): 156-163.

Wang, A.G.; Xia, T.; Ru, R.; Yuan, J.; Chen, X.; Yang, K. and Yang, K. (2004): Antagonistic effect of selenium on oxidative stress, DNA damage, and apoptosis induced by fluoride in human hepatocytes. Fluoride; 37(2): 107-116.

Wang, W. and Li, Y. (2002): Environmental epidemiology of fluorine and its effects on health. Soil Environ. Sci. 11(4): 383-387.

Xin, T.; ZiRong, X.U. and Yi, Z.W. (2006): Effects of dietary fluoride levels on growth, serum indexes and antioxidant system in growing pigs. Turk. J. Vet. Anim. Sci., 30: 65-70.

Yoshimi, N.; Kazuhiro, T.; Masamitsu, S.; Satoshi, M. and Hiseaki, H. (2009): Comparison of bee products based on assays of antioxidant 
capacities. BMC Complementary and Alternative Medicine.9: 4.

Yoshizumi, K.; Nisshioka, N. and Tsuji, T. (2005): Xanthine oxidase inhibitory activity and hypouricemia effect of propolis in rats. Yakgaku Zasshi. Mar.; 125(3): 315-21.

Zhan, X.A.; Wang, M.; Xu, Z.R. and Li, J.X. (2006): Toxic effects of $\mathrm{F}$ on kidney function and histology in young pigs Fluoride 39(1)22-26.

\section{دور شمع العل المضاد للاكسدة على التاثير السمى لقلوريد الصوديوم على الكبد والكلى الكي

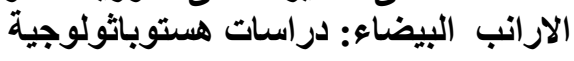

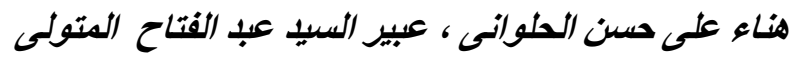 \\ Email: hanaeg2002@yahoo.com_Assiut University web-site: www.aun.edu.eg}

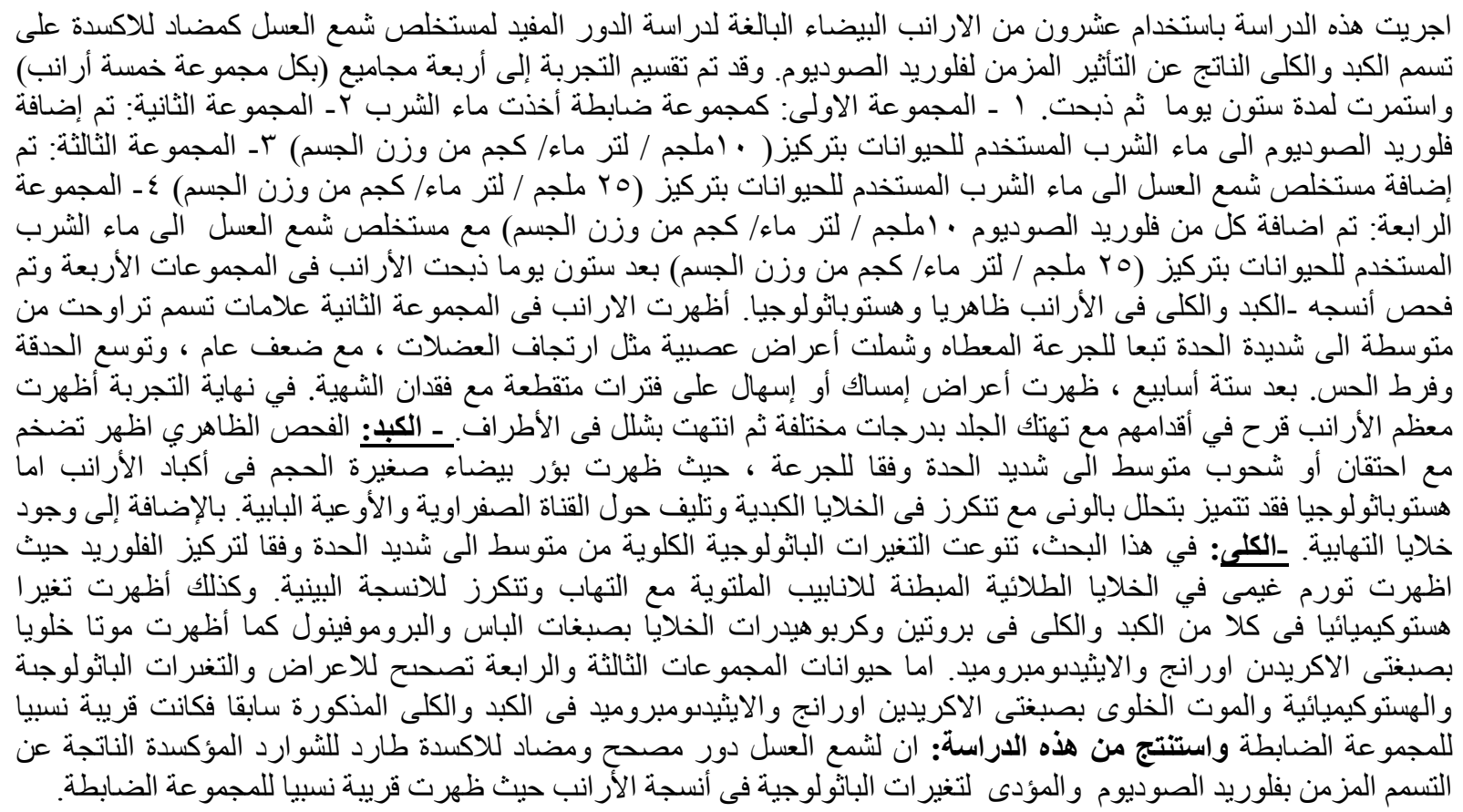

